\title{
Pengaruh Lingkungan Kerja dan Stress Kerja Terhadap Kinerja Pada Pegawai Kantor Camat Tebing Tinggi Kabupaten Empat Lawang
}

\author{
Gunawan \\ Sekolah Tinggi IImu Ekonomi Serelo Lahat, gunawanserelo@gmail.com
}

\begin{abstract}
ABSTRAK
Penelitian ini bertujuan untuk mengetahui dan menguji ada atau tidaknya pengaruh lingkungan kerja dan stress kerja terhadap Kinerja Pada Pegawai Kantor Camat Tebing Tinggi Kabupaten Empat Lawang. Persamaan regresi berganda $Y=47.258+0.68 \mathrm{X} 1+-0.106 \mathrm{X} 2+\mathrm{e}$. Hasil uji $\mathrm{t}$ menunjukkan bahwa bahwa variabel Lingkungan Kerja ( 0.729 ) jadi 0,729 >0,05 artinya variabel Lingkungan Kerja memiliki pengaruh signifikan terhadap Kinerja pegawai pada Kantor Camat Tebing Tinggi Kabupaten Empat Lawang.Variabel Stress Kerja (0.608) jadi $0.608>0,05$ artinya variabel Stress Kerja memiliki pengaruh signifikan terhadap Kinerja pegawai pada Kantor Kantor Camat Tebing TinggiKabupatenEmpatLawang. Dari hasil perhitungan didapatkan nilai $F$ hitung secara keseluruhan dalam penelitian ini adalah sebesar 0,185 Sedangkan nilai $\mathrm{F}$ Tabel pada derajat kebebasan $\mathrm{df}=0,05$, dengan demikian nilai $\mathrm{F}$ hitung $>\mathrm{f}$ tabel sehingga $\mathrm{H}_{0}$ ditolak, artinya $\mathrm{Hi}$ diterima dengan nilai $0,185>0,05$.Artinya secara bersama-sama Lingkungan Kerja dan Stress kerja berpengaruh secara signifikan terhadap Kinerja pegawai Pada Kantor Camat Tebing Tinggi Kabupaten Empat Lawang.
\end{abstract}

Kata Kunci : Lingkungan kerja, stres kerja, Kinerja

\begin{abstract}
This study aims to identify and test whether or not the influence of the work environment and work stress on the performance of the employees of the Tebing Tinggi sub-district office, Empat Lawang Regency. Multiple regression equation $Y=47.258+0.68 X 1+-0.106 X 2+e$. The results of the $t$-test indicate that the Work Environment variable (0.729) becomes $0.729>0.05$, meaning that the Work Environment variable has a significant influence on employee performance at the Tebing Tinggi Subdistrict Office, Empat Lawang Regency. Work Stress Variable (0.608) so $0.608>0.05$ means Work Stress variable has a significant effect on employee performance at the Tebing Tinggi Sub-District Office, Empat Lawang Regency. From the calculation results, the overall calculated $F$ value in this study is 0.185 While the $F$ table value at degrees of freedom $d f=0.05$, thus the calculated $F$ value $>f$ table so that $\mathrm{HO}$ is rejected, meaning $\mathrm{Hi}$ is accepted with a value of $0.185>0.05$ This means that together the work environment and work stress have a significant effect on employee performance at the Tebing Tinggi sub-district office, Empat Lawang Regency.
\end{abstract}

Keywords: work environment, work stress, performance

\section{A. PENDAHULUAN}

Sumber daya manusia adalah faktor penting / sentral dalam satu organisasi,apapun bentuk serta tujuannya,organisasi dibuat berdasarkan berbagai visi untuk kepentingan manusia dan dalam pelaksanaannya misi tersebut dikelola oleh manusia, jadi manusia merupakan faktor strategis dalam semua kegiatan organisasi.Kesemua itu membutuhkan kondisi pegawai yang stabil,baik itu menyangkut kondisi tempat bekerja,maupun banyaknya pekerjaan yang harusdiselesaikan,sehingga akan menimbulkan perasaan puas atau senang dalam menyelesaikannya semua. 
Dalam dasar-dasar ilmu Organisasi ada tiga (3) faktor yang mempengaruhi perilaku, yang dapat dikelompokan kedalam variabel lingkungan, yaitu keadaan alam disekitar manusia,kelompok damn kebudayaan.

Lingkungan kerja adalah suatu lingkungan dimana karyawan/pegawai bekerja, sedangkan kondisi kerja merupakan kondisi dimana karyawan tersebut bekerja. Dengan demikian sebenarnya kondisi kerja termasuk salah satu unsur lingkungan kerja, dengan kata lain lingkungan kerja didalam suatu organisasi perusahaan bukan hanya terdiri dari kondisi kerja saja melainkan kondisi kerja ditambah dengan beberapa aspek lain yang membentuk lingkungan kerja.

Dalam manajemen sumber daya manusia Stres Kerja adalah suatu kondisi dimana terdapat satu atau beberapa faktor ditempat kerja yang berinteraksi dengan pekerja sehingga bisa mempengaruhi kondisi prilaku pegawai .Stres kerja akan muncul bila terdapat kesenjangan antara kemampuan individu dengan tuntutantuntutan dari pekerjaannya.

Kinerja merupakan hasil dari suatu proses yang dilakukan manusia.Berdasarkan hal tersebut, maka kinerja atau prestasi kerja merupakan hasil kerja yang dicapai seseorang menurut ukuran yang berlaku,dalam kurun waktu tertentu berkenaan dengan pekerjaan serta perilaku dan tindakannya. Adapun indikator yang mempengaruhi suatu kinerja itu antara lain yaitu :

a) Kualitas Output

b) Kuantitas Output

c) Waktu Kerja

d) Kerjasama dengan rekan kerja yang lain.

Kantor Camat Tebing Tinggi sebagai sebagai unsur pemerintahan yang melayani masyarakat, harus mampu memberikan pelayanan serta memberikan solusi yang baik bagi masyarakat.Unsur pegawai dalam kantor tersebut merupakan kunci pokok dalam memberikan pelayanan.

Pegawai dituntut bekerja sebaik mungkin dengan didasarkan rasa tanggung jawab.Namun kondisi para pegawai yang ada dikantor Camat tersebut malah sebaliknya, dalam bekerja kondisi lingkungan kantor yang sangat kurang mendukung seperti terletak tepat dijalan lintas yang berdampingan dengan pertokoan yang sangat sibuk pada waktu pagi hari,bangunan yang sudah banyak yang rusak, sarana seperti meja kursi yang sudah kurang layak digunakan serta sistem penerangan yang kurang baik sehingga pada waktu terjadi pemadaman listrik tidak akan genset untuk digunakan sebagai alat bantu penerangan.

Kondisi tersebut sangat bedampak pada pegawai yang kurang semangat dalam menyelesaikannya, dikarenakan kurang dikuasai oleh pegawai itu sendiri, dalam pemberian insentif / honor khususnya kegiatan yang dilaksanakan dikantor tersebut tidak seimbang dengan beban kerja / kegiatan yang dilaksanakan.Tidak ada peluang untuk mendukung jabatan relatif kecil. Tidak adanya dorongan dan pengawasan langsung yang dilaksanakan oleh pimpinan kantor sehingga pekerjaan banyak yang tidak diselesaikan oleh. Hubungan sosial antara pegawai kurang harmonis, sehingga sebagian pegawai tidak saling perdulikan dalam menyelesaikan pekerjaan yang ada .

Situasi kerja yang nyaman baik itu dalam organisasi itu sendiri maupun diluar organisasi akan berdampak pada mental setiap pegawai. Pegawai akan merasa nyaman, tenang dan bergairah dalam melaksanakan setiap pekerjaan yang dilakukan, sehingga akan berdampak pada hasil kerja yang diharapkan. 
Sudah barang tentu setiap pegawai dalam menjalankan pekerjaan tanpa ada beban secara mental akan mudah dapat menyelesaikan segala jenis pekerjaan asalkan situasi yang ada sangat mendukung, dengan demikian sudah jelas setiap pegawainya akan merasa nilai tersendiri dalam menyelesaikan pekerjaan tersebut, rasa senang, bangga serta timbul rasa puas. Dengan segala daya dan upaya sudah barang tentu terjalin suatu sikap ingin selalu menyelesaikan pekerjaan tersebut.

Dengan kondisi yang harmonis, nyaman, aman yang dirasakan dan dimiliki oleh setiap pegawai akan menimbulkan kepuasan kerja yang dirasakan oleh setiap pegawai, sehingga akan lebih mudah untuk mewujudkan visi dan misi yang menjadi tujuan dari sebuah organisasi itu sendiri.

\section{B. KAJIAN TEORI}

\section{1) Pengertian Manajemen Sumber Daya Manusia}

Menurut Irham Fahmi (2017:1), Manajemen Sumber Daya Manusia adalah rangkaian aktivitas organisasi yang diarahkan untuk menarik,mengembangkandan mempertahankan tenaga kerja yang efektif.

\section{2) Pengertian Kinerja}

Menurut Sedarmayanti (2017:285), Kinerja adalah sesuatu yang secara actual orang kerjakan dan dapat diobserasi.Kinerja mencakup tindakan-tindakan dan perilaku yang relevan dengan tujuan organisasi.

\section{3) Pengertian Lingkungan Kerja}

Menurut Sunyoto dalam Oktariansyah (2020:166), lingkungan kerja adalah segala sesuatu yang ada disekitar para pekerja yang dapat mempengaruhi dirinya dalam menjalankan tugas-tugas yang dibebankan, misalnya kebersihan, musik, penerangan dan lain-lain.

Secara fisik lingkungan dapat berupa lokasi tempat kerja, kondisi bangunan dan kerja sama. Baik fisik dan non fisik meliputi kedisiplinan dan kerja sama.

\section{4) Pengertian Stress Kerja}

Hasibuan.S.P. dalam Usman, dkk (2021:20) mendefinisakan stres kerja adalah suatu kondisi ketegangan yang mempengaruhi emosi, proses berpikir, dan kondisi seseorang. Stress Kerja dapat didefinisikan suatu reaksi psikologis dan fisik terhadap kondisi internal atau lingkungan yang diperpanjang dan kecakapan-kecakapan adaptif individu yang bekerja terlalu berat

\section{5) Kerangka Konsep Penelitian}

Kerangka Pemikiran merupakan alur penalaran yang didasarkan pada tema masalah penelitian yang digambarkan secara menyeluruh dan sistematik setelah mempelajari teori yang mendukung judul penelitian.

Menurut Sugiono (2017:60) kerangka berpikir merupakan model konseptual tentang bagaimana teori berhubungan dengan berbagai fakor yang telah di idenifikasi sebagai masalah yang penting.

Dalam penelitian ini untuk mewujudkan arah dari pemecahan dan penganalisaan masalah yang dihadapi, maka terlebih dahulu perlu dikemukan gambaran yang berupa kerangka pemikiran sebagai berikut : 


\section{Gambar Kerangka Konsep Penelitian}

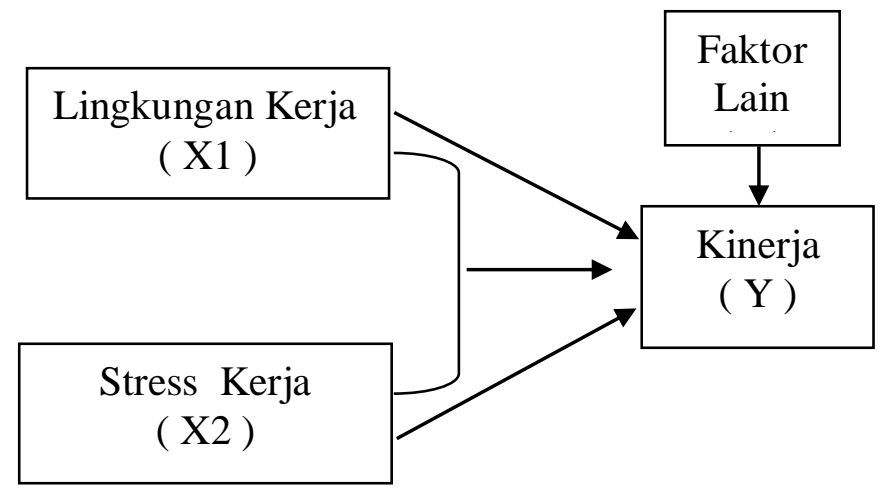

\section{Keterangan :}

Uraian kerangka konsep penelitian, diatas dapat dijelaskan bahwa antara Lingkungan Kerja (X1), Strees Kerja (X2) dan Kinerja ( $Y$ ) mempunyai hubungan yang tidak dapat dipisahkan artinya apabila Lingkungan kerja mampu untuk diatasi, serta stress kerja dapat ditekan maka jelas akan meningkatkan kinerja setiap pegawai dalam menjalankan pekerjaannya sesuai dengan bidang-masing.

\section{Hipotesis}

Menurut Sugiyono (2017:63) yang menjelaskan Hipotesis merupakan jawaban sementara, oleh karena itu rumusan masalah penelitian biasanya disusun dalam bentuk kalimat pertanyaan.

Pada penelitian ini dikemukan hipotesis sebagai berikut :

1. Diduga ada Pengaruh Lingkungan kerja terhadap Kinerja Pegawai Pada Kantor Camat Merapi Barat Kabupaten Lahat

2. Diduga ada Pengaruh Stress kerja terhadap Kinerja Pegawai Pada Kantor Camat Merapi Barat Kabupaten Lahat

3. Diduga ada Pengaruh Lingkungan kerjadan Stress kerja terhadap Kinerja Pegawai Pada Kantor Camat Merapi Barat Kabupaten Lahat

\section{METODE PENELITIAN}

1) Populasi dan Sampel

$>$ Populasi

Menurut Sugiyono (2016:90), Populasi adalah wilayah generalisasi yang terdiri atas objek/subjek yang mempunyai kualitas dan karakteristik tertentu yang ditetapkan oleh peneliti untuk dipelajari dan kemudian ditarik kesimpulannya.Adapun Populasi dalam penelitian ini adalah seluruh Pegawai Kantor Camat Merapi Barat Kabupaten Lahat berjumlah 33 Orang.

\section{$>$ Sampel}

Menurut Sugiyono (2016:91), Sampel adalah bagian dari jumlah dan karakteristik yang dimiliki oleh populasi tersebut. Dan cara pengambilan sampel dalam penelitian ini adalah dengan cara sampling jenuh (sensus) yaitu tektik penentuan sampel dengan cara mengambil semua populasi yang ada. Adapun sampel yang diambil dalam penelitian ini sebanyak 33 orang Pegawai Kantor Camat Merapi Barat Kabupaten Lahat. 


\section{2) Jenis dan Sumber Data \\ $>$ Jenis Data}

Menurut Sugiyono (2016:15), jenis data dibagi menjadi dua yaitu:

a. Data Kualitatif

Data kualitatif adalah data yang dinyatakan dalam bentuk kata, kalimat, skema dan gambar.Data yang berupa non bilangan atau non angka dapat mencakup hampir semua data non-numerik. Data ini dapat menggunakan kata-kata untuk menggambarkan fakta dan fenomena yang diamati.

b. Data Kuantitatif

Data kuantitatif adalah data yang berbentuk angka yang dapat diinput ke dalam skala pengukuran statistik.

\section{$>$ Sumber Data}

Menurut Sujarweni (2016:77), Sumber data adalah subjek dari mana asal data penelitian itu diperoleh. Apabila peneliti misalnya menggunakan kuesioner atau wawancara dalam pengumpulan datanya, maka sumber data disebut responden, yaitu orang yang merespon atau menjawab pertanyaan, baik tertulis maupun lisan. Berdasarkan sumbernya, data dibagi menjadi :

a. Data Primer

Data primer adalah data yang diperoleh dari responden melalui kuesioner, kelompok focus, dam panel, atau juga data hasil wawancara peneliti dengan nara sumber. Data yang diperoleh dari data primer ini harus diolah lagi.Sumber data langsung memberikan data kepada pengumpul data.

b. Data Sekunder

Data sekunder adalah data yang didapat dari catatan, buku, majalah berupa laporan keuangan publikasi perusahaan, laporan pemerintah, artikel, buku-buku sebagai teori, majalah, dan lain sebagainya.Data yang diperoleh dari data sekunder ini tidak perlu diolah lagi.Sumber yang tidak langsung memberikan data pada pengumpulan data.

\section{3) Metode Pengumpulan Data}

Menurut Sujarweni, (2016:78), metode pengumpulan data merupakan cara yang dilakukan peneliti untuk menangkap atau menjaring informasi kuantitatif dan responden sesuai lingkup penelitian. Adapun metode data yang digunakan, yaitu :

1. Studi Pustaka (Library Research)

Studi Pustaka dilakukan untuk mendapatkan data atau informasi berupa catatancatatan, dokumen atau yang berhubungan dengan penelitian yang dilaksanakan.

2. Studi Lapangan (Field Research)

Studi Lapangan adalah penelitian yang dilakukan secara langsung dilapangan.

Adapun teknik-teknik yang dilakukan dalam studi lapangan antara lain :

a. Observasi

Observasi adalah pengamatan dan pencatatan secara sistematik terhadapa gejala yang tampak pada objek penelitian.

b. Wawancara

Wawancara adalah salah satu instrumen yang digunakan untuk menggali data secara lisan. Hal ini haruslah dilakukan secara mendalam agar kita mendapatkan data yang valid dan detail. 
c. Kuisioner

Kuisioner merupakan teknik pengumpulan data yang dilakukan dengan cara memberi separangkat pertanyaan atau pernyataan tertulis kepada para responden untuk dijawab.Jawaban dari kuisioner ini berupa antara lain :

$>$ Sangat Setuju (SS) dengan skor nilai : 5

$>$ Setuju (S) dengan skor nilai : 4

$>$ Kurang Setuju (KS) dengan skor nilai: 3

$>$ Tidak Setuju (TS) dengan skor nilai: 2

> Sangat Tidak Setuju(STS) denganskor nilai : 1

\section{4) Identifikasi Variabel Penelitian}

Menurut Sugiyono (2016:38). Variabel penelitian adalah suatu atribut atau sifat atau nilai dari orang, obyek atau kegiatan yang mempunyai variasi tertentu yang ditetapkan oleh peneliti untuk dipelajari dan kemudian ditarik kesimpulannya. Variabel yang digunakan dalam penelitian dapat diklasifikasikan menjadi dua:

a. Variabel Bebas (Independen)

Variabel bebas merupakan variabel yang mempengaruhi atau yang manjadi sebab perubahannya atau timbulnya variabel dependen (terikat).

b. Variabel Terikat (dependen)

Variabel terikat merupakan variabel yang dipengaruhi atau yang menjadi akibat karena adanya variabel bebas.

\section{5) Metode Analisis Data}

Metode analisis yang digunakan dalam penelitian ini yaitu analisis kuantitatif. Analisi kuantitatif adalah analisis yang meggunakan perhitungan angka-angka dengan rumus statistik. Dalam menyelesaikan data tersebut penulis menggunakan bantuan software SPSS (Statistical package for the social science) versi 20.0.

\section{a) Uji Kualitas Data}

Dalam penelitian ini penulis menggunakan Uji kualitas data. Uji Kualitas data digunakaan untuk mengukur variabel dengan menggunakan instrumen kuisioner sehingga dilakukan kualitas data terhadap data yang diperoleh. Agar mendapatkan hasil penelitian yang sesuai dengan tujuan penelitian, maka diperlukan metode analisis data yang benar, dengan menggunakan rumus sebagai berikut :

\section{$>\quad$ Uji Validitas Data}

Menurut Sugiyono (2016:363) Validitas merupakan derajad ketepatan antara data yang terjadi pada obyek penelitian dengan daya yang dapat dilaporkan oleh peneliti. Dengan demikian data yang valid adalah data yang tidak berbeda antara data yang dilaporkan oleh peneliti dengan data yang sesungguhnya terjadi pada obyek penelitian. Uji validitas dilakukan untuk memastikan seberapa baik suatu instrumen digunakan untuk mengukur konsep yang seharusnya diukur. Menurut Sugiyono untuk menguji validitas konstruk dilakukan dengan cara mengkorelasikan antara skor butir pertanyaan dengan skor totalnya.Uji Validitas adalah Suatu ukuran yang menunjukkan tingkat-tingkat kevalidan atau keahliaan suatu instrumen. Maka sebuah instrumen dikatakan valid apabila mampu mengukur apa yang diinginkan, serta dapat mengungkap data dari variabel yang diteliti secara tepat. Maka cara untuk mengukur validitas dengan menggunakan rumus Product Moment angka kasar sebagai berikut : 
Rumus :

$$
r_{x y}=\frac{n \sum x y-\sum x \cdot \sum y}{\sqrt{n} \sum x^{2}-\sum(x)^{2} \sqrt{n} \sum y^{2}-\sum(y)^{2}}
$$

Keterangan :

$$
\begin{aligned}
& r_{x y}=\text { Koefisien korelasi antara variabel } \mathrm{x} \text { dan } \mathrm{y} \\
& \mathrm{n}=\text { Jumlah responden } \\
& \mathrm{x}=\text { Skor butir } \\
& \mathrm{y}=\text { Skor total }
\end{aligned}
$$

Karena dengan angka kasar relative lebih mudah dan akan dapat menghindari angka pecahan, sedangkan mengenai perhitungan korelasinya berdasarkan ketentuan bahwa jika $r_{x y}>r r_{\text {tabel }}$ signifikan 5\% berarti item (butir soal) dinyatakan valid, sebaliknya jika $r_{x y}<r r_{\text {tabel }}$, maka butir soal tidak valid sekaligus tidak memiliki persyaratan.

$>\quad$ Uji Reliabilitas

Menurut Sujarweni (2014:85), uji reliabilitas merupakan ukuran suatu kestabilan dan konsistensi responden dalam menjawab hal yang berkaitan dengan kontrukkontruk pertanyaan yang merupakan dimensi suatu variabel dan disusun dalam suatu bentuk kuisioner. Uji Reliabilitas menunjukkan sejauh mana suatu instrumen dapat memberikan hasil pengukuran yang konsisten apabila pengukuran dilakukan berulang-ulang. Dalam Pengukuran reliabilitas tersebut dilakukan dengan rumus Alpha dengan rumus :

$$
r_{11}=\left(\frac{k}{(k-1)}\right)\left(1-\frac{\sum \sigma_{b}^{2}}{\sigma^{2}}\right)
$$

Keterangan :

$r_{11}=$ Koefisien reliabilitas instrument

$\mathrm{K}=$ Banyak butir pertanyaan atau banyaknya soal

$\sum \sigma_{b}^{2}=$ Jumlah varians butir

$\sigma_{1}^{2}=$ Varians total

Kriteria besarnya koefisien reliabilitas sebagai berikut :

$0,80<r 11 \leq 1,00=$ Reliabilitas sangat tinggi

$0,60<\mathrm{r} 11 \leq 0,80=$ Reliabilitas tinggi

$0,40<\mathrm{r} 11 \leq 0,60=$ Reliabilitas cukup

$0,20<\mathrm{r} 11 \leq 0,40=$ Reliabilitas rendah

$0,00<\mathrm{r} 110,20=$ Reliabilitas sangat rendah

Dikatakan reliabilitas jika antara korelasi yang diperoleh > tabel taraf signifikan $5 \%$. Dikatakan tidak realibel jika angka korelasi < rtabel pengujian. 


\section{b) Uji Asumsi Klasik}

\section{$>$ Uji Normalitas Data}

Uji normalitas bertujuan untuk mengetahui apakah dalam model regresi, variabel pengganggu atau residual memiliki distribusi normal.Model regresi yang baik adalah model regresi yang memiliki distribusi data normal atau mendekati normal. Ada dua cara untuk mendeteksi apakah residual berdistribusi normal atau tidak normal yaitu dengan analisis grafik dan uji statistik non-parametrik KolmogrovSmirnov (K-S). Cara pertama sering digunakan untuk melihat normalitas data yaitu dengan melihat histogram residual, yaitu jika data menyebar disekitar garis diagonal dan mengikuti arah garis diagonal atau grafik histogramnya menunjukkan pola distribusi normal, maka model regresi memenuhi asumsi normalitas. Adapun cara kedua yang digunakan untuk menentukan data berdistribusi normal atau tidak yaitu dengan menggunakan uji statistik non-parametrik Kolmogrov-Smirnov (K-S). Jika nilai sig (2-tailed) lebih besar dari pada 5\%, maka data berdistribusi normal (Ghozali, 2011:165).

\section{$>\quad$ Uji Heterokedasitas}

Heterokedasitas adalah apabila kesalahan atau residual yang diamati tidak memiliki variabel yang konstan. Kondisi heterokedastisitas sering terjadi pada data cross section atau data yang diambil dari beberapa responden pada suatu waktu tertentu. Hasil uji heterokedastisitas glejser adalah bahwa nilai thitung pada masingmasing variabel < ttabel atau nilai probabilitas (Asymp.Sig) > 0,05, maka data variabel tidak terjadi heterokedasitas.

$>\quad$ Uji Multikoloneritas

Uji multikoloneritas bertujuan untuk menguji apakah model regresi ditemukan adanya korelasi antar variabel bebas (independen). Model regresi yang baik seharusnya tidak terjadi korelasi antar variabel independen.Untuk mengetahui ada tidaknya multikoloneritas dalam model regresi adalah menganalisis matrik korelasi variabel-variabel independen. Jika antar variabel independen cukup tinggi (umumnya diatas 0,90), maka hal ini merupakan indikasi adanya multikoloneritas. Multikoloneritas juga dapat dilihat nilai Tolerance dan Variance Inflation Factor (VIF). Kedua ukuran ini menunjukkan setiap variabel independen manakan yang dijelaskan oleh variabel independen lainnya. Nilai cut off yang umumnya digunakan adalah nilai tolerance $\leq 0,10$ atau sama dengan nilai VIF $\geq 0,10$. Pengujian uji multikoloneritas dilakukan dengan menggunakan bantuan program SPSS for Windows 20.0.

\section{c) Uji Statistik}

\section{Uji Statistik Deskriptif}

Menurut Sugiyono (2016: 238) dalam buku Metode Penelitian Manajemen Uji Statistik Deskriptif adalah statistik yang digunakan untuk menganalisis data dengan cara mendeskripsikan atau menggambarkan data yang telah terkumpul sebagaimana adanya tanpa bermaksud membuat kesimpulan yang berlaku untuk umum atau generalisasi. Statistik deskriptif antara lain adalah penyajian data melalui tabel, grafik, diagram lingkaran, pictogram, perhitungan modus, median, mean (pengukuran tendasi sentra), perhitungan rata-rata dan standar deviasi, perhitungan persentase. 


\section{Uji Statistik Inferensial}

Menurut Sugiyono (2016: 240) dalam buku Metode Penelitian Manajemen Uji Statistikinferensial adalah tekhnik statistik yang digunakan untuk menganalisis data sampel dah hasilnya diberlakukan untuk populasi. Statistik ini akan cocok digunakan bila sampel diambil dari populasi yang jelas dan teknik pengambilan sampel dari populasi itu dilakukan secara random. Berikut ini perhitungan statistik sebagai berikut:

Regresi Linier Berganda

Regresi ini digunakan untuk mengetahui Pengaruh Lingkungan Kerja dan Stress Kerja TerhadapKinerja Pegawai Pada Kantor Camat Merapi Barat Kabupaten Lahat

Adapun rumusnya sebagai berikut :

$$
\mathrm{Y}=\mathrm{a}+b_{1} X_{1}+b_{2} X_{2}+\mathrm{e}
$$

Keterangan :

$\mathrm{Y}=$ Kinerja

$\mathrm{a}=$ Konstanta

$b_{1}=$ Koefisien regresi untuk $\left(\mathrm{X}_{1}\right)$

$b_{2}=$ Koefisien regresi untuk X2

$X_{1}=$ Lingkungan Kerja

$X_{2}=$ Stress Kerja

e $=$ standart eror

\section{$>$ Koefisien Korelasi}

Menurut Sugiyono (2016: 240) dalam buku Metode Penelitian Manajemen, Koefisien korelasi digunakan untuk mengetahui seberapa kuat hubungan antara variabel bebas dengan variabel terikat, dapat diketahui dengan besarnya koefisien korelasi.

Sedangkan untuk mengetahui keeratan hubungan antara variabel-variabel bebas secara bersama-sama terhadap variabel terikat, maka nilai koefisien kolerasi ganda digunakan formula berikut:

$$
\begin{aligned}
& \sqrt{r_{y 1}{ }^{2}+r_{y 2}{ }^{2}-2 r_{y 1} \cdot r_{y 2} r_{y 12}} \\
& R_{y 1.2}=\frac{1-r_{12}{ }^{2}}{}
\end{aligned}
$$

Keterangan :

Ry.x1.x2 = Koefisien Kolerasi Ganda

Koefisien Determinasi

Untuk menyatakan besar kecilnya sumbangan variabel-variabel bebas terhadap variabel terikat dapat ditentukan dengan rumus koefisien determinasi sebagai berikut:

$$
R^{2}=r^{2} \times 100 \%
$$

Keterangan :

$\mathrm{R}^{2}=$ Nilai Koefisien Diterminasi

$\mathrm{r} \quad=$ Nilai Koefisien Kolerasi

\section{Uji Hipotesis}

\section{$>\quad$ Uji Parsial (Uji t)}

Uji Parsial digunakan untuk mengetahui signifikan ada tidaknya pengaruh variabel bebas terhadap variabel terikat secara parsial atau sendiri-sendiri, sehingga sudah bisa diketahui apakah dugaan yang sudah ada dapat diterima atau ditolak. 
Langkah-langkah Uji parsial sebagai berikut :

a) Uji t Lingkungan Kerja $\left(X_{1}\right)$ Terhadap Kinerja $(Y)$

Dengan cara:

1. Menentukan Formulasi Ho dan Hi

Ho : $\beta=0$ : Berarti tidak ada pengaruh antara variabel indenpenden dengan variabel dependen secara terpisah.

$\mathrm{Hi}: \beta \neq$ : Berarti ada pengaruh antara indenpendent dengan variabel dependen secara terpisah.

2. Level of Significant $\alpha=5 \%$

3. Kriteria Penguji

\section{Gambar Kriteria Pengujian Uji Parsial}

Lingkungan Kerja $\left(X_{1}\right)$ terhadap Kinerja (Y)

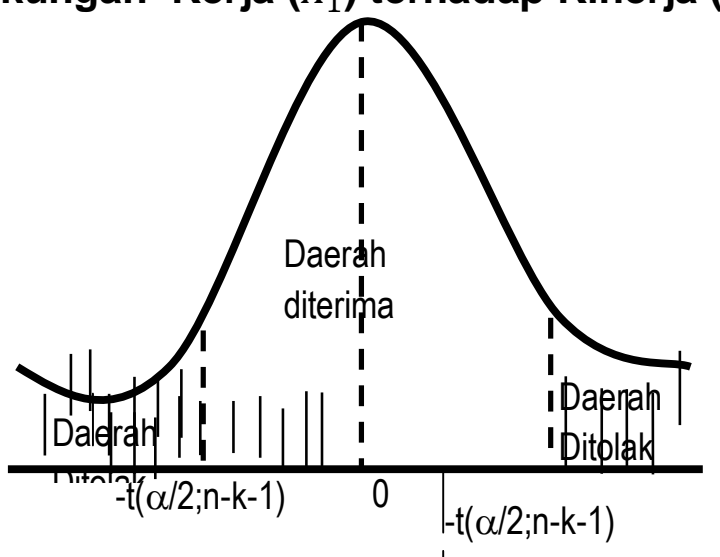

Ho diterima apabila $-t_{\text {tabel }} \leq t_{\text {hitung }} \leq t_{\text {tabel }}$

Ho ditolak apabila $t_{\text {hitung }}>t_{\text {tabel }}$ atau $t_{\text {hitung }}>-t_{\text {tabel }}$

4. Pengujian nilai $t$

$$
\begin{aligned}
& \mathrm{t}=\frac{b i}{S b i} \\
& \text { Sbi }=\sqrt{\frac{S 2 y \cdot 12}{\sqrt{\frac{x 2(1-R I 2)}{}}}} \\
& S^{2} y^{12}=\frac{J K(S)}{(n-k-1)}
\end{aligned}
$$

Keterangan :

Sbi = Galat baku Koefisien bi

$S^{2}$ y. $1=$ Galat Baku Taksiran dalam populasi

$R i^{2} \quad=$ Koefisien antara $X_{1}$ dan $X_{2}$

5. Kesimpulan

Membandingkan antara $t_{\text {hitung }}$ dengan $t_{\text {tabel }}$, maka didapat dan diketahui ada tidaknya pengaruh Lingkungan Kerja $\left(X_{1}\right)$ terhadap Kinerja $(Y)$ Pegawai Pada Kantor Camat Merapi Barat Kabupaten Lahat

b) Uji t Stress Kerja $\left(X_{2}\right)$ Terhadap Kinerja (Y)

1. Menetukan formasi Ho dan $\mathrm{Hi}$

Ho : $\beta=0$ : Berarti tidak ada pengaruh antara variabel indenpenden dengan variabel dependen secara terpisah. 
$\mathrm{Hi}: \beta \neq$ : Berarti ada pengaruh antara indenpendent dengan variabel dependen secara terpisah.

2. Level of significant $\alpha=5 \%$

3. Kriteria Pengujian.

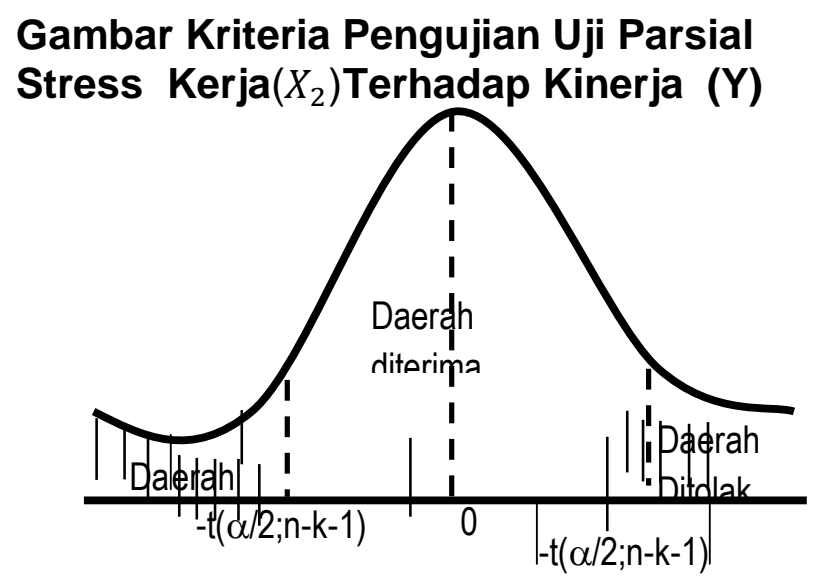

Ho diterima apabila $-t_{\text {tabel }} \leq t_{\text {hitung }} \leq t_{\text {tabel }}$

Ho ditolak apabila $t_{\text {hitung }}>t_{\text {tabel }}$ atau $t_{\text {hitung }}>-t_{\text {tabel }}$

4. Pengujian nilai $t$

$$
\mathbf{t}=\frac{b i}{S b i}
$$

$$
\begin{aligned}
& S^{2} y .12 \\
& \mathrm{Sbi}=\sqrt{\sum x \frac{2}{i j}}\left(1-R i^{2}\right) \\
& \mathrm{S}^{2} \mathrm{y} .12=\frac{J K(S)}{(n-k-1)}
\end{aligned}
$$

Keterangan :

Sbi = Galat baku koefisien bi

$S^{2} y .12=$ Galat baku taksiran dalam Populasi

$R i^{2} \quad=$ koefisien antara $X_{1}$ dan $X_{2}$

5. Kesimpulan

Membandingkan antara $t_{\text {hitung }}$ dengan $t_{\text {tabel }}$, maka didapat dan diketahui ada tidaknya pengaruh Stress Kerja $\left(X_{2}\right)$ terhadap Kinerja(Y) Pegawai Pada Kantor Camat Merapi Barat Kabupaten Lahat

\section{$>\quad$ Uji Simultan (F)}

Uji $\mathrm{F}$ digunakan untuk mengetahui signifikan pengaruh variabel Lingkungan Kerja $\left(X_{1}\right)$ dan Stress Kerja $\left(X_{2}\right)$ secara bersama-sama terhadap Kinerja (Y) Pegawai Pada Kantor Camat Merapi Barat Kabupaten Lahat Menetukan formasi Ho dan $\mathrm{Hi}$

1. Ho: $\beta=0$ : Berarti tidak ada pengaruh antara Linkgungan Kerja $\left(X_{1}\right)$ dan Stress $\operatorname{Kerja}\left(X_{2}\right)$ terhadap Kinerja $(Y)$

$\mathrm{Hi}: \beta \neq$ : Berarti ada pengaruh Lingkungan $\operatorname{Kerja}\left(X_{1}\right)$ dan Stress Kerja $\left(X_{2}\right)$ terhadap Kinerja (Y). 
2. Penentuan level of significant $5 \%$ dipilih $\alpha=0,05$

3. Kriteria pengujian

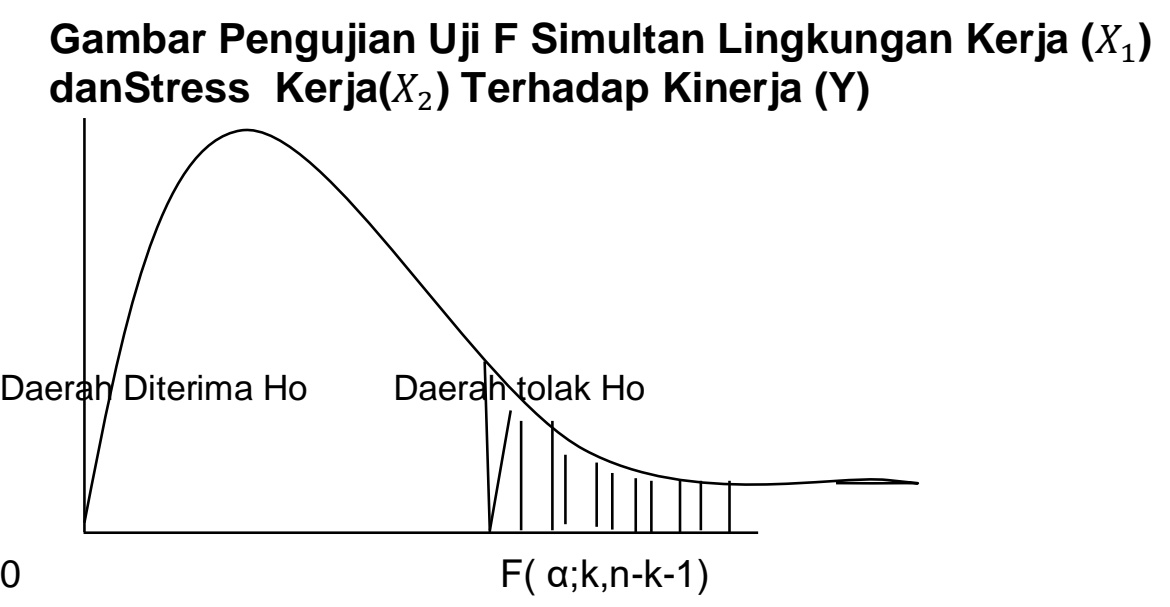

Ho diterima apabila : $\mathrm{F}$ hitung $\leq \mathrm{F}$ table

Ho ditolak apabila : F hitung $\geq F$ table

Perhitungan nilai $\mathrm{F}$

$\mathbf{F}=\frac{\mathrm{JKR} / \boldsymbol{k}}{\mathrm{JKG} /(\mathbf{n}-\mathbf{k}-\mathbf{1})}$

Dengan:

$$
\begin{aligned}
& \mathrm{JKR}=\mathrm{b}_{1} \Sigma \mathrm{x}_{1} \mathrm{y}+\mathrm{b}_{2} \Sigma \mathrm{x}_{2} \mathrm{y} \\
& \mathrm{JKT}=\Sigma \mathrm{y}^{2} \\
& \mathrm{JKG}=\mathrm{JKT}-\mathrm{JKR}
\end{aligned}
$$

Dimana :

$$
\begin{aligned}
& \mathrm{k}=\text { jumlah variabel independent } \\
& \mathrm{n}=\text { jumlah sampel } \\
& \mathrm{F}=\mathrm{F} \text { hitung }
\end{aligned}
$$

4. Kesimpulan

Nilai $\mathrm{F}$ hitungdiperoleh kemudian dibandingkan dengan $\mathrm{F}$ table. Apabila $\mathrm{H}_{0}$ ditolak berarti ada pengaruh varibel independen ( $\mathrm{F}$ ) dengan variabeldependen $(\mathrm{Y})$.

5. Pengujian uji $\mathrm{F}$ dilakukan dengan menggunakan bantuan program SPSS for Windows V 20.0.

\section{HASIL DAN PEMBAHASAN}

\section{1) Uji Kualitas Data}

\section{$>\quad$ Uji Validitas}

Pada penelitian ini ada tiga variabel yang diteliti yaitu variabel Lingkungan Kerja(X1), Stress Kerja (X2), sebagai variabel bebas dan variabel Kinerja (Y) sebagai variabel terikat.

Uji validitas dilakukan dengan cara menghitung korelasi antara masing-masing pernyataan dengan skor total memakai rumus teknik korelasi product moment. Secara statistik, angka korelasi yang diperoleh harus diuji terlebih dahulu untuk menyatakan apakah nilai korelasi yang didapat adalah signifikan atau tidak. Caranya yaitu dengan membandingkan angka korelasi hasil dengan koefisien korelasi tabel 
pada taraf $\alpha=0.05$ dengan $n=35$. Bila koefisien korelasi hasil perhitungan $>$ dari koefisien korelasi tabel pada taraf $\alpha=0.05$, maka pernyataan-pernyataan tersebut signifikan, yang berarti bahwa pernyataan yang bersangkutan adalah valid.

Pada penelitian ini ada empat variabel yang diteliti yaitu variabel Lingkungan Kerja (X1), Stress Kerja (X2), sebagai variabel bebas dan variabel Kepuasan Kerja (Y) sebagai variabel terikat.

Sebelum melakukan analisis secara statistik terhadap 35 responden tersebut perlu dilakukan uji validitas dan reliabilitas terhadap kuesioner untuk menjamin bahwa kuesioner yang digunakan merupakan alat uji yang valid dan reliabel. Suatu kuesioner dikatakan valid jika pertanyaan-pertanyaan yang ada pada kuesioner tersebut mampu mengungkapkan sesuatu yang akan diukur.

Dengan akta lain, mampu memperoleh data yang tepat dari variabel yang diteliti. Sedangkan reliabilitas adalah tingkat keandalan kuesioner. Suatu kuesioner dikatakan reliabel jika jawaban seseorang terhadap pertanyaan kuesioner tersebut konsisten dari waktu ke waktu, atau jika kuesioner tersebut dicobakan secara berulang-ulang kepada kelomok yang sama akan menghasilkan data yang sama.

Sedangkan uji reliabilitas dilakukan dengan menggunakan Cronbach's Alpha. Angka yang didapat melalui metode Cronbach's Alpha kemudian dibandingkan dengan koefisien korelasi pada taraf $\alpha=0.05$ pada $n=35$. Bila nilai Cronbach's Alpha lebih besar, maka varibel penelitian dikatakan reliabel atau terpercaya.Untuk mempermudah perhitungan, digunakan SPSS 20.0.

\section{a. Variabel Lingkungan Kerja ( X1)}

Uji validitas untuk variabel Lingkungan Kerja disajikan pada tabel berikut ini.

Tabel Uji Validitas Butir Variabel Lingkungan Kerja

\begin{tabular}{|c|c|c|c|}
\hline Koefisien Korelasi & r hitung & r tabel & Keterangan \\
\hline Butir 1 & 0.009 & 0.349 & Tidak Valid \\
\hline Butir 2 & 0.425 & 0.349 & Valid \\
\hline Butir 3 & 0.536 & 0.349 & Valid \\
\hline Butir 4 & 0.372 & 0.349 & Valid \\
\hline Butir 5 & 0.614 & 0.349 & Valid \\
\hline Butir 6 & 0.425 & 0.349 & Valid \\
\hline Butir 7 & 0.567 & 0.349 & Valid \\
\hline Butir 8 & 0.552 & 0.349 & Valid \\
\hline Butir 9 & 0.389 & 0.349 & Valid \\
\hline Butir 10 & 0.513 & 0.349 & Valid \\
\hline
\end{tabular}

Sumber : diolah dari program SPSS 20.00

Berdasarkan tabel diatas, 1 dari 10 butir pernyataan pada variable Lingkungan Kerja adalah valid. Sedangkan output nilai Cronbach's Alpha untuk uji reliabilitas instrumen pada variabel Lingkungan Kerja dengan menggunakan SPSS 20.0 menghasilkan nilai thitung (0.614 )Karena nilai yang diperoleh lebih besar dari ttabel (0.349) maka dapat disimpulkan bahwa instrumen untuk variabel Lingkungan Kerja adalah reliabel. 


\section{b. Variabel Stress Kerja ( X2 )}

Uji validitas untuk variabel Stress Kerja disajikan pada berikut ini.

Tabel Uji Validitas Butir Variabel Stress Kerja

\begin{tabular}{|c|c|c|c|}
\hline Koefisien Korelasi & r hitung & r tabel & Keterangan \\
\hline Butir 1 & 0.406 & 0.349 & Valid \\
\hline Butir 2 & 0.548 & 0.349 & Valid \\
\hline Butir 3 & 0.568 & 0.349 & Valid \\
\hline Butir 4 & 0.528 & 0.349 & Valid \\
\hline Butir 5 & 0.103 & 0.349 & Tidak Valid \\
\hline Butir 6 & 0.437 & 0.349 & Valid \\
\hline Butir 7 & 0.383 & 0.349 & Valid \\
\hline Butir 8 & 0.548 & 0.349 & Valid \\
\hline Butir 9 & 0.709 & 0.349 & Valid \\
\hline Butir 10 & 0.479 & 0.349 & Valid \\
\hline
\end{tabular}

Sumber : Data yang diolah SPSS.20.0

Berdasarkan tabel diatas, 1 dari 10 butir pernyataan pada variabel Stress Kerja adalah valid. Sementara itu, nilai Cronbach's Alpha guna uji reliabilitas instrumen nilai thitung lebih besar dari ttabel, sehingga dapat diambil kesimpulan bahwa instrumen untuk variabel Stress Kerja adalah reliabel.

\section{c. Variabel Kinerja ( $Y$ )}

Uji validitas untuk variabel Kinerja disajikan pada berikut ini.

Tabel Uji Validitas butir variabel Kinerja ( $Y$ )

\begin{tabular}{|c|c|c|c|}
\hline Koefisien Korelasi & r hitung & r tabel & Keterangan \\
\hline Butir 1 & 0.541 & 0.349 & Valid \\
\hline Butir 2 & 0.744 & 0.349 & Valid \\
\hline Butir 3 & 0.553 & 0.349 & Valid \\
\hline Butir 4 & 0.637 & 0.349 & Valid \\
\hline Butir 5 & 0.188 & 0.349 & Tidak Valid \\
\hline Butir 6 & 0.574 & 0.349 & Valid \\
\hline Butir 7 & 0.231 & 0.349 & Tidak Valid \\
\hline Butir 8 & 0.394 & 0.349 & Valid \\
\hline Butir 9 & 0.501 & 0.349 & Valid \\
\hline Butir 10 & 0.211 & 0.349 & Tidak Valid \\
\hline
\end{tabular}

Sumber : Data yang diolah.

Berdasarkan tabel diatas, 3 dari 10 butir pernyataan pada variabel Kinerja adalah valid. Uji reliabilitas dengan metode Cronbach's Alpha menghasilkan nilai thitung (0.744) lebih besar dari nilai ttabel (0.349) hal ini menunjukan bahwa instrumen untuk variabel Kinerjareliabel.

\section{$>\quad$ Uji Realibiltas}

Setelah menentukan validitas instrument penelitian, tahap selanjutnya adalah mengukur reliabilitas data dan instrument penelitian. Reliabilitas adalah suatu angka indeks yang menunjukkan konsistensi suatu alat pengukur didalam mengukur gejala yang sama (Husein Umar, 2010:194). Uji ini mengukur ketepatan alat ukur. Suatu alat ukur disebut memiliki reliabilitas yang tinggi jika alat ukur yang digunakan stabil. Pengujian reliabilitas dalam penelitian ini untuk menunjukkan konsistensi suatu alat pengukur dalam penelitian melalui nilai alpha cronbach karena menggunakan jenis data likert/essay. 
Teknik ini dapat menafsirkan korelasi antara skala diukur dengan semua variabel yang ada (Husein Umar, 2010:207). Dalam pengujian reliabilitas ini, peneliti menggunakan metode statistik Cronbach Alpha dengan signifikansi yang digunakan sebesar 0,60 dimana jika nilai Cronbach Alpha dari suatu variabel lebih besar dari 0,60 maka butir pertanyaan yang diajukan dalam pengukur instrument tersebut memiliki reliabilitas yang memadai. Sebaliknya, jika nilai Cronbach Alpha dari suatu variabel lebih kecil dari 0,60 maka butir pertanyaan tersebut tidak reliable.

a. Uji Realibilitas Variabel Lingkungan (X1)

\section{Tabel Reliability Statistics}

\begin{tabular}{|l|l|}
\hline Cronbach's Alpha & N of Items \\
\hline
\end{tabular}

,855

10

Dari tabel diatas ,dapat dilihat dari thitung lebih besar dari ttabel $(0,855>0,60)$, artinya variabel Lingkungan Realibilitas / dipercaya.

b. Uji Realibilitas Variabel Stress Kerja (X2)

Tabel Reliability Statistics

\begin{tabular}{|c|c|}
\hline Cronbach's Alpha & N of Items \\
\hline, 722 & 10 \\
\hline
\end{tabular}

Dari tabel diatas ,dapat dilihat dari thitung lebih besar dari ttabel $(0,722>0,60)$, artinya variabel Lingkungan Realibilitas / dipercaya .

c. Uji Realibilitas Variabel Kinerja (Y)

\section{Tabel Reliability Statistics}

\begin{tabular}{|c|c|}
\hline Cronbach's Alpha & N of Items \\
\hline, 731 & 10 \\
\hline
\end{tabular}

Dari tabel diatas ,dapat dilihat dari thitung lebih besar dari ttabel $(0,731>0,05)$, artinya variabel Lingkungan Realibilitas / dipercaya .

\section{2) Uji Prasyarat Analisis}

\section{$>\quad$ Uji Asumsi Normalitas}

Uji Asumsi Normalitas pada penelitian ini dilakukan untuk mengetahui tingkat hubungan antara variabel Lingkungan dan Stress Kerja dengan Kinerja pegawai di Kantor Kantor Camat Merapi Barat Kabupaten Lahat

Adanya hubungan antara ketiga variabel tersebut dapat juga dilihat dari gambar plot masing-masing variabel bebas dengan variabel terikat (Kinerja). 


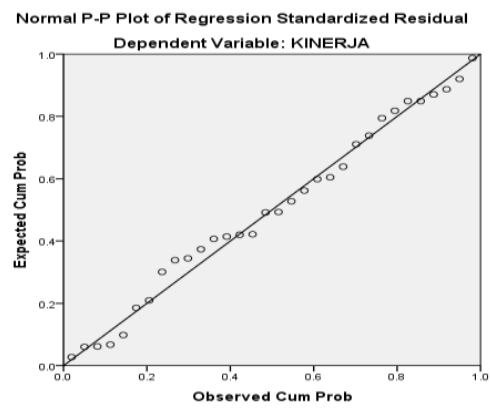

Plot variabel : a. Lingkungan vs Stress Kerja ,

\section{Gambar Hubungan Antara Ketiga Variabel}

\section{$>\quad$ Uji multikolonearitas}

Uji multikolonearitas bertujuan untuk menguji apakah model regresi ditemukan adanya korelasi antar variabel bebas (independen). Model regresi yang baik seharusnya tidak terjadi korelasi antar variabel independen. Untuk mengetahui ada tidaknya multikolonearitas dalam model regresi adalah menganalisis matrik korelasi variabel-variabel independen. Jika antar variabel independen cukup tinggi (umumnya diatas 0,90), maka hal ini merupakan indikasi adanya multikolonieritas. Multikolonieritas juga dapat dilihat nilai Tolerance dan Variance Inflation Factor (VIF). Kedua ukuran ini menunjukkan setiap variabel independen mana yang dijelaskan oleh variabel independen lainnya. Nilai cut off yang umumnya digunakan adalah nilai tolerance $\leq 0,10$ atau sama dengan nilai VIF $\geq 0,10$. Pengujian uji multikolonearitas dilakukan dengan menggunakan bantuan program SPSS for Windows 20.0.

\section{Tabel Hasil Uji multikolonearitas}

Coefficients $^{a}$

\begin{tabular}{|cc|c|c|c|c|c|c|c|}
\hline & \multicolumn{2}{|c|}{$\begin{array}{c}\text { Unstandardized } \\
\text { Coefficients }\end{array}$} & $\begin{array}{c}\text { Standardized } \\
\text { Coefficients }\end{array}$ & & & \multicolumn{2}{|c|}{$\begin{array}{c}\text { Collinearity } \\
\text { Statistics }\end{array}$} \\
\cline { 3 - 5 } \cline { 7 - 9 } & Model & B & Std. Error & Beta & t & Sig. & Tolerance & VIF \\
\hline 1 & (Constant) & $-2,868$ & 5,751 & &,- 499 &, 621 & & \\
& LINGKUNGAN &, 168 &, 100 &, 140 & 1,677 &, 103 & 1,000 & 1,000 \\
& STRESS KERJA &, 887 &, 085 &, 869 & 10,403 &, 000 & 1,000 & 1,000 \\
\hline
\end{tabular}

a. Dependent Variable: KINERJA

Sumber : Data yang diolah

Dari hasil Uji multikolonearitas diatas, pada tabel tersebut dapat dilihat nilai VIF unutk variabel Lingkungan adalah sebesar sebesar 1,000, untuk varaibel Stress Kerja Nilai VIF sebesar 1,000.Maka data penelitian ini bebas dari asumsi multikolonearitas.

\section{$>\quad$ Uji Heteroskedastisitas}

Heteroskedastisitas adalah apabila kesalahan atau residual yang diamati tidak memiliki variabel yang konstan. Kondisi heteroskedastisitas sering terjadi pada data cross section atau data yang diambil dari beberapa responden pada suatu waktu tertentu. Hasil uji heteroskedastisitas glejser adalah bahwa nilai thitung pada masingmasing variabel < ttabel atau nilai probabilitas (Asymp.Sig) > 0,05, maka data variabel tidak terjadi heteroskedastisitas. 
Scatterplot

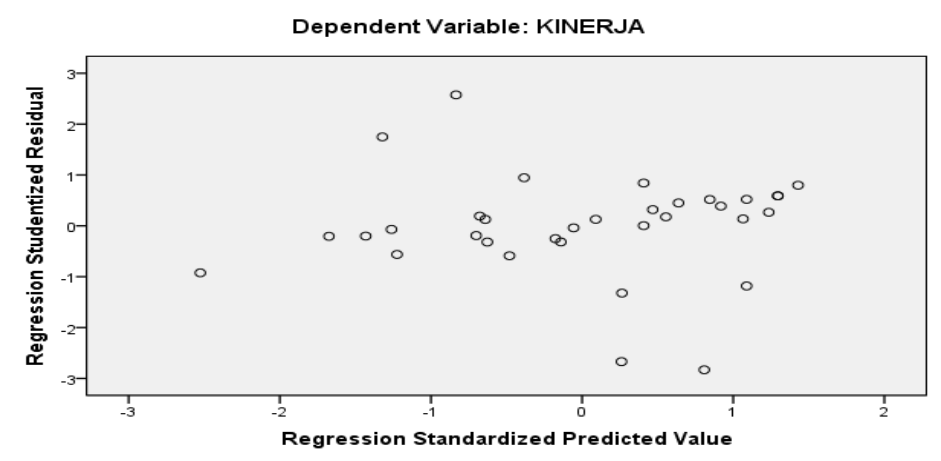

Hasil output diatas dapat diketahui bahwa titik-titik tidak membentuk pola yang jelas dan titik-titik menyebar diatas dan dibawah angka 0 pada sumbu $Y$. Jadi dapat disimpulkan bahwa tidak terjadi masalah heteroskedastisitas dalam model regresi.

\section{3) Uji Statistik}

\section{$>\quad$ Analisis Statistik Deskriptif}

Data dikumpulkan dari 35 responden yang kesemuanya merupakan pegawaipegawai pada Kantor Camat Merapi Barat Kabupaten Lahat

Seluruh responden memberikan persepsi mereka terhadap serangkaian pernyataan yang dikelompokan dalam variabel bebas dan variabel terikat. Variabel bebas terdiri dari ,Lingkungan Kerja(X1), Stress Kerja (X2) dan variabel terikatnya adalah Kinerja(Y).

Tabel Statistic Variabel

Statistics

\begin{tabular}{|c|c|c|c|c|}
\hline & & LINGKUNGAN & STRESS & KINERJA \\
\hline \multirow[t]{2}{*}{$N$} & Valid & 35 & 35 & 35 \\
\hline & Missing & 0 & 0 & 0 \\
\hline \multicolumn{2}{|c|}{ Mean } & 46.1714 & 45.4286 & 45.6000 \\
\hline \multicolumn{2}{|c|}{ Std. Error of Mean } & .42503 & .40643 & .47314 \\
\hline \multicolumn{2}{|c|}{ Median } & 46.0000 & 45.0000 & 47.0000 \\
\hline \multicolumn{2}{|c|}{ Mode } & $44.00^{\mathrm{a}}$ & 43.00 & $43.00^{\mathrm{a}}$ \\
\hline \multicolumn{2}{|c|}{ Std. Deviation } & 2.51450 & 2.40448 & 2.79916 \\
\hline \multicolumn{2}{|c|}{ Variance } & 6.323 & 5.782 & 7.835 \\
\hline \multicolumn{2}{|c|}{ Skewness } & -.441 & .187 & -.782 \\
\hline \multicolumn{2}{|c|}{$\begin{array}{l}\text { Std. Error of } \\
\text { Skewness }\end{array}$} & .398 & .398 & .398 \\
\hline \multicolumn{2}{|c|}{ Kurtosis } & .484 & -1.686 & .907 \\
\hline \multicolumn{2}{|c|}{ Std. Error of Kurtosis } & .778 & .778 & .778 \\
\hline \multicolumn{2}{|c|}{ Range } & 11.00 & 7.00 & 13.00 \\
\hline \multicolumn{2}{|c|}{ Minimum } & 39.00 & 43.00 & 37.00 \\
\hline \multicolumn{2}{|c|}{ Maximum } & 50.00 & 50.00 & 50.00 \\
\hline
\end{tabular}




\begin{tabular}{|ll|r|r|r|} 
Sum & & 1616.00 & 1590.00 & 1596.00 \\
Percentiles & 25 & 44.0000 & 43.0000 & 43.0000 \\
& 50 & 46.0000 & 45.0000 & 47.0000 \\
& 75 & 48.0000 & 48.0000 & 48.0000 \\
\hline
\end{tabular}

a. Multiple modes exist. The smallest value is shown

\section{Deskriptif Lingkungan Kerja ( X1)}

Dalam mengetahui deskripsi data dari Variabel Lingkungan Kerja(X1) dari 35 responden atau sampel yang diambil data,diperoleh rata hitung (mean) 46,17 titik tengah (median) sebesar 46,00 kemudian nilai yang sering muncul (Mode) adalah 44,00 simpangan baku (Standar Devisiasi) $=2,51$ dan tingkat penyebaran data (Variance) $=6,232$, Kemudian rentangan (Range) $=11$ : skor minimum dari data (Min) $=39$ :skor maksimum dari data $(\operatorname{Max})=50$.

\section{Deskriptif Variabel Stress Kerja (X2)}

Dalam mengetahui deskripsi data dari Variabel Stress Kerja (X2) dari 35 responden atau sampel yang diambil data,diperoleh rata hitung (mean) 45,43 titik tengah (median) sebesar 45,00 kemudian nilai yang sering muncul (Mode) adalah 43,00 simpangan baku (Standar Devisiasi) $=2,494$ dan tingkat penyebaran data $($ Variance $)=5,782$, Kemudian rentangan (Range) $=7$ : skor minimum dari data (Min) $=43$, :skor maksimum dari data $($ Max $)=50$.

Untuk kenormalan distribusi data doperoleh bila nilai (kecendrongan/skewness dan keruncingan/kurtosis),dibandingkan dengan Standart Eror nya dan hasilnya (-2 sampai dengan +2 , (Singgih,2010:183), untuk kecendrongan (skewness) dihasilkan 0,000 sedangkan keruncingan (kurtosis) dihasilkan 0000 nilai yang dihasilkan menggambarkan data cenderung berdistribusi normal.adapu histogram dari variabel Pelatihan (X2) dapat dilihat sebagai berikut :

\section{Deskriptif Variabel Kinerja( $Y$ )}

Dalam mengetahui deskripsi data dari Variabel Kinerja $(\mathrm{Y})$ dari 35 responden atau sampel yang diambil data,diperoleh rata hitung (mean) 45,60 titik tengah (median) sebesar 47,00 kemudian nilai yang sering muncul (Mode) adalah 43,00 simpangan baku (Standar Devisiasi) $=2,799$ dan tingkat penyebaran data (Variance) $=7,835$, Kemudian rentangan (Range) $=13$ : skor minimum dari data $(\operatorname{Min})=37$, skor maksimum dari data $(\operatorname{Max})=50$.

Untuk kenormalan distribusi data diperoleh bila nilai (kecendrongan/skewness dan keruncingan /kurtosis), dibandingkan dengan Standart Eror nya dan hasilnya (-2 sampai dengan +2 .untuk kecendrongan (skewness) dihasilkan -0,000 sedangkan keruncingan (kurtosis) dihasilkan 0000 nilai yang dihasilkan menggambarkan data cenderung berdistribusi normal.adapu histogram dari variabel Kinerja $(Y)$ dapat dilihat sebagai berikut : 


\section{Gambar Histogram Kemiringan Data}

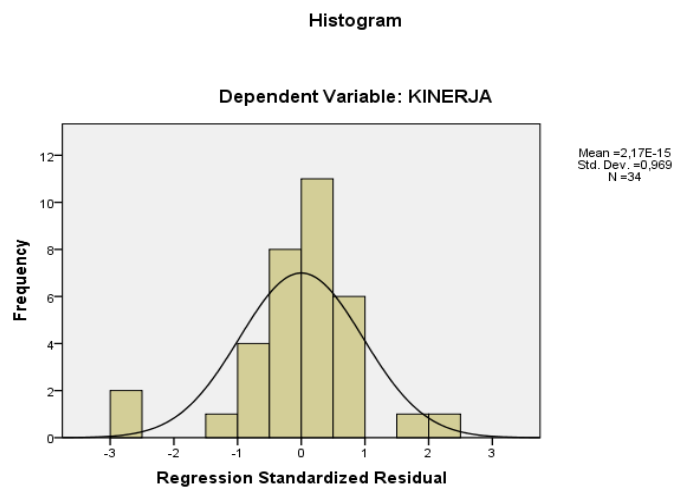

\section{a. Analisis Statistik Inferensial}

\section{$>$ Analisis Regresi Linier Berganda}

Regresi linier berganda digunakan untuk mengetahui pengaruh Lingkungan $\left(X_{1}\right)$ dan Stress Kerja $\left(X_{2}\right)$ terhadap Kinerja $(Y)$. Perhitungan persamaan regresi linier berganda dapat dilihat pada tabel berikut :

\section{Tabel Koefisien Regresi Berganda}

\section{Coefficients $^{\mathrm{a}}$}

\begin{tabular}{|c|c|c|c|c|c|c|c|}
\hline \multirow[b]{2}{*}{ Model } & \multicolumn{2}{|c|}{$\begin{array}{l}\text { Unstandardized } \\
\text { Coefficients }\end{array}$} & \multirow{2}{*}{\begin{tabular}{|c|}
$\begin{array}{c}\text { Standardized } \\
\text { Coefficients }\end{array}$ \\
Beta
\end{tabular}} & \multirow[b]{2}{*}{$\mathbf{t}$} & \multirow[b]{2}{*}{ Sig. } & \multicolumn{2}{|c|}{$\begin{array}{l}\text { Collinearity } \\
\text { Statistics }\end{array}$} \\
\hline & B & $\begin{array}{l}\text { Std. } \\
\text { Error }\end{array}$ & & & & Tolerance & VIF \\
\hline $1 \quad$ (Constant) & 47.258 & 12.597 & & 3.752 & .001 & & \\
\hline LINGKUNGAN.K & .068 & .196 & .062 & .349 & .729 & .996 & 1.004 \\
\hline STRESS & -.106 & .205 & -.091 & -.517 & .608 & .996 & 1.004 \\
\hline
\end{tabular}

a. Dependent Variable: KINERJA

Diolah dengan SPSS 20.0

Berdasarkan tabel atas, persamaan regresi linier berganda untuk mengestimasi variabel terikat (Kinerja) dengan menggunakan seluruh variabel bebas (Lingkungan Kerjadan Stress Kerja) adalah sebagai berikut :

$Y=47.258+0.68 \times 1-0.106 \times 2+e$

Dimana $\mathrm{y}=$ Kinerja, $\mathrm{X} 1=$ Lingkungan Kerja, $\mathrm{X} 2=$ Stress Kerja

Persamaan regresi diatas memiliki makna :

1) Jika Lingkungan Kerjadan Stress Kerjatidak ada, maka Kinerjapegawai cenderung positif. Hal ini ditunjukan oleh besaran konstanta sebesar 47.258.

2) Jika variabel Lingkungan Kerja(X1) dinaikan sebesar 1satuan , sementara variabel bebas lainnya tetap, akan meningkatkan Kinerjapegawai sebesar 0,068 unit. 
3) Jika Stress Kerja (X2) dinaikkan sebesar 1 satuan, sementara variabel bebas lainnya tetap, akan menurunkan Kinerjamempengaruhi sebesar -0.106 unit.

\section{$>\quad$ Koefisien Korelasi}

Koefisien korelasi digunakan untuk mengetahui hubungan antara variabelvariabel bebas terhadap variabel terikat, maka nilai koefisien kolerasi digunakan sebagai berikut :

Tabel Koefisien Korelasi Model Summary

\begin{tabular}{|c|c|c|c|c|c|c|c|c|c|}
\hline \multirow[b]{2}{*}{ Model } & \multirow[b]{2}{*}{$n$} & \multirow[b]{2}{*}{ R Square } & \multirow[b]{2}{*}{$\begin{array}{c}\text { Adjusted R } \\
\text { Square }\end{array}$} & \multirow{2}{*}{$\begin{array}{l}\text { Std. Error } \\
\text { of the } \\
\text { Estimate }\end{array}$} & \multicolumn{4}{|c|}{ Change Statistics } & \multirow[b]{2}{*}{$\begin{array}{l}\text { Durbin- } \\
\text { Watson }\end{array}$} \\
\hline & & & & & re Change & \begin{tabular}{|c|}
$F$ \\
Change
\end{tabular} & \begin{tabular}{|c|c|}
$d f$ & $d f$ \\
1 & 2 \\
\end{tabular} & \begin{tabular}{|c} 
Sig. F \\
Change
\end{tabular} & \\
\hline- &, $881^{\mathrm{a}}$ & ,776 & ,762 & 2,37967 & ,776 & 55,570 & 232 & ,000 & 2,469 \\
\hline
\end{tabular}

a. Predictors: (Constant), STRESS KERJA, LINGKUNGAN

b. Dependent variable KINERJA

\section{$>\quad$ Uji Koefisien Determinasi}

Analisis ini digunakan untuk mengetahui seberapa besar sumbangan yang diberikan variabel bebas terkait,yang ditunjukkan dalam persentase. Hasilnya adalah sebagai berikut :

\section{Tabel Model Summary}

\begin{tabular}{|l|l|l|l|l|l|}
\hline Model & $\mathbf{R}$ & R Square & $\begin{array}{l}\text { Adjusted R } \\
\text { Square }\end{array}$ & $\begin{array}{l}\text { Std. Error of } \\
\text { the Estimate }\end{array}$ & $\begin{array}{l}\text { Durbin - } \\
\text { Watson }\end{array}$ \\
\hline 1 & $.107^{\mathrm{a}}$ & .011 & -.050 & 2.86880 & 2.86880 \\
\hline
\end{tabular}

a. Predictors: (Constant), LINGKUNGAN .K , STRESS

b. Dependent Variable: KINERJA

Berdasarkan tabel diatas bahwa hasil analisis koefisien determinasi (R2) dapat diperoleh Rsquare (R2) sebesar 0,11. Berarti dapat djelaskan bahwa Lingkungan Kerja dan Stress Kerja mempunyai pengaruh sebesar $11 \%$ terhadap Kinerja ,sedangkan sisanya sebesar $89 \%$ dipengaruh oleh variabel yang tidak diteliti.

\section{4) Uji Hipotesis}

\section{$>\quad$ Uji Parsial (Uji T)}

Uji parsial (Uji t) digunakan untuk menunjukkan seberapa jauh pengaruh suatu variabel independen (bebas) secara individual dalam menerangkan variasi variabel dependen (terikat). Uji parsial pada penelitian ini digunakan untuk menguji pengaruh variabel Lingkungan Kerjadan Stress Kerja secara sendiri-sendiri terhadap Kinerja pegawai Pada Kantor Camat Tebing TinggiKabupaten Empat Lawang

\section{a. Pengujian Pengaruh Variabel Lingkungan $\left(X_{1}\right)$ Terhadap Kinerja $(Y)$}

Hipotesis yang diuji adalah :

1) $\mathrm{H}_{0}$ : varibel Lingkungan Kerjatidak berpengaruh terhadap variabel Kinerja pegawai.

$\mathrm{H}_{1}$ : variabel Lingkungan Kerja berpengaruh terhadap variable Kinerja pegawai. 


\section{Tabel Coeficients}

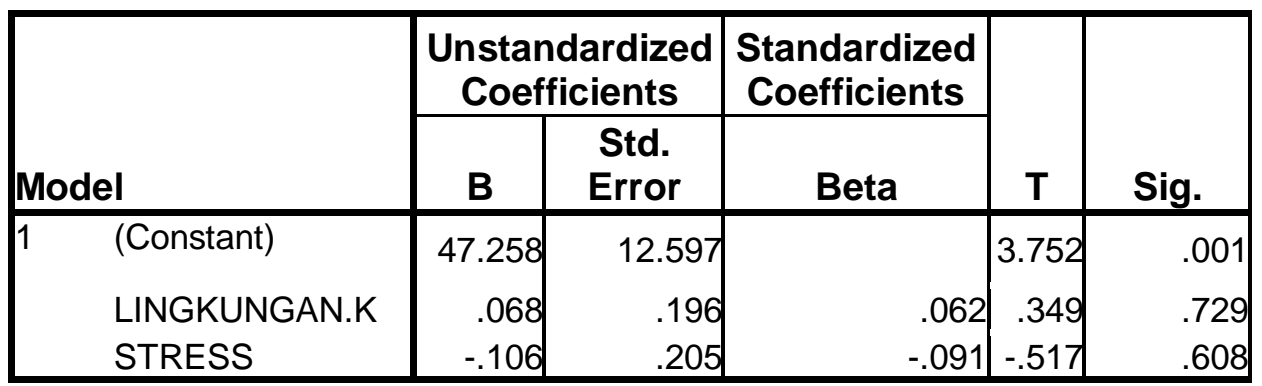

a. Dependent Variable: KINERJA

Berdasarkan tabel diatas, dapat disimpulkan bahwa variabel Lingkungan Kerja (0.729) jadi 0,729 > 0,05 artinya variabel Lingkungan Kerjamemiliki pengaruh signifikan terhadapKinerjapegawai pada Kantor Camat Merapi Barat Kabupaten Lahat.

\section{Gambar Kreteria Pengujian Uji Parsial Lingkungan Kerja Terhadap Kinerja}

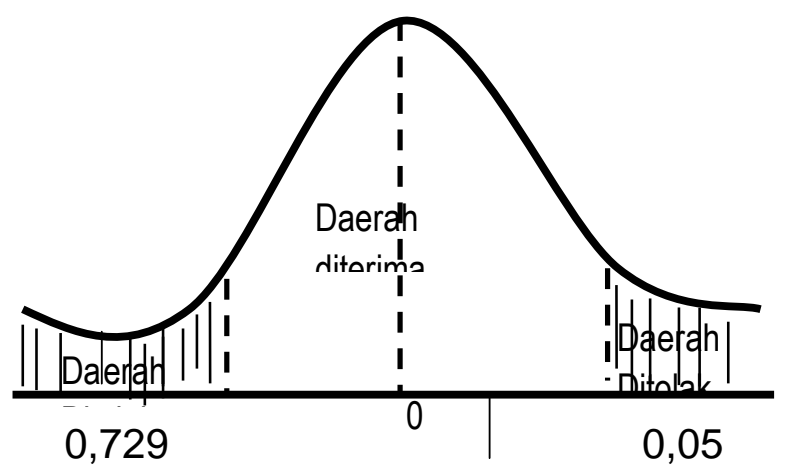

\section{b. Pengujian Pengaruh Variabel Stress Kerja (X2) Terhadap Kinerja (Y)}

2) $\mathrm{H}_{0}$ : varibel Stress Kerja tidak berpengaruh terhadap variabel Kinerja pegawai.

$\mathrm{H}_{1}$ : variabel Stress Kerja berpengaruh terhadap variabel Kinerja pegawai.

$\mathrm{H}_{0}$ diterima apabila $\mathrm{S} \mathrm{Sig}>0.05$ atau t hitung $>\mathrm{t}$ Tabel

$\mathrm{H}_{1}$ diterima jika $\mathrm{t}$ Sig $>0.05$ atau $\mathrm{t}$ hitung $<\mathrm{t}$ Tabel

Tabel Coeficients

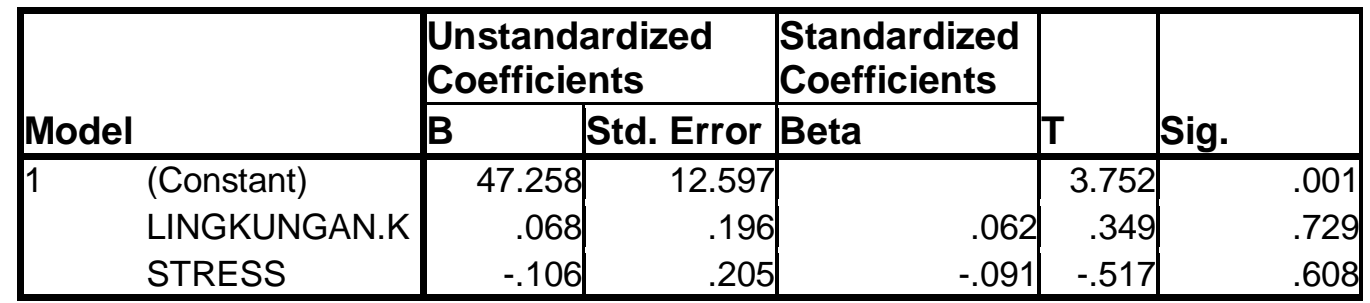

a. Dependent Variable: KINERJA

Berdasarkan tabel diatas, dapat disimpulkan bahwa variabel Stress Kerja ( 0.608 ) jadi $0.608>0,05$ artinya variabel Stress Kerja memiliki pengaruh signifikan terhadapKinerjapegawai pada Kantor Camat Merapi Barat Kabupaten Lahat. 


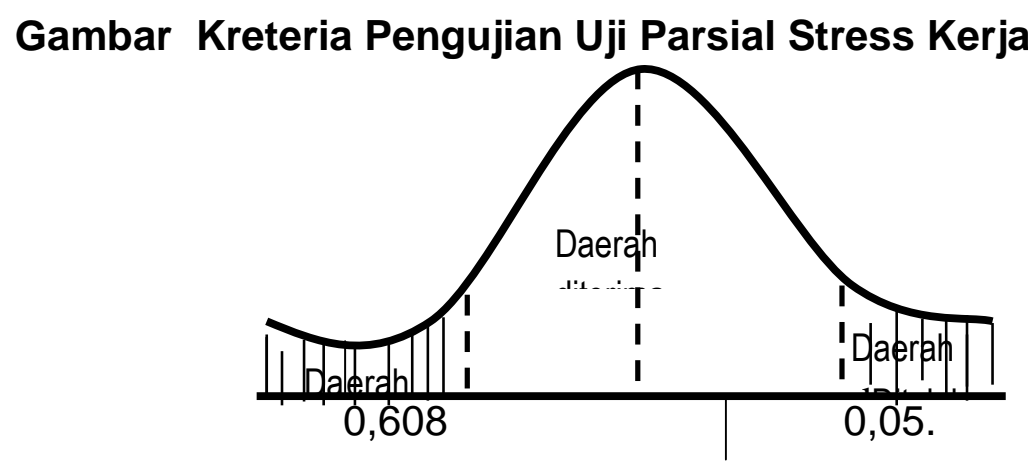

\section{$>\quad$ Uji Simultan ( $f$ )}

Pada penelitian ini, hipotesis yang diuji adalah :

$\mathrm{H}_{0}$ : Lingkungan Kerjadan Stress Kerja secara bersama-sama tidak berpengaruh terhadap Kinerja.

$\mathrm{H}_{1}$ : Lingkungan Kerjadan Stress Kerja secara bersama-sama berpengaruh terhadap Kinerja

Adapun kriteria pengujiannya adalah :

$\mathrm{H}_{0}$ diterima jika $\mathrm{P}$ Value $<0.05$ atau $\mathrm{F}$ Hitung $<\mathrm{F}$ Tabel

$\mathrm{H}_{1}$ diterima jika $\mathrm{P}$ Value $>0.05$ atau $\mathrm{F}$ Hitung $>\mathrm{F}$ Tabel

Hasil perhitungan untuk pengujian secara simultan dilakukan dengan bantuan software SPSS 20.00 Hasil secara rinci perhitungan untuk maksud pengujian tersebut disajikan pada tabel berikut ini

\section{Tabel Uji Simultan}

ANOVA $^{b}$

\begin{tabular}{|r|r|r|rr|r|r|}
\hline \multicolumn{1}{|c|}{ Model } & $\begin{array}{r}\text { Sum of } \\
\text { Squares }\end{array}$ & Df & Mean Square & F & Sig. \\
\hline $1 \quad$ Regression & 3.039 & 2 & 1.519 & .185 & $.832^{\mathrm{a}}$ \\
Residual & 263.361 & 32 & & 8.230 & & \\
Total & 266.400 & 34 & & & & \\
\hline
\end{tabular}

a. Predictors: (Constant), LINGKUNGAN KERJA, STRESS KERJA

b. Dependent Variable: KINERJA

Dari hasil perhitungan didapatkan nilai $F$ hitung secara keseluruhan dalam penelitian ini adalah sebesar 0,185 Sedangkan nilai $F$ Tabel pada derajat kebebasan df $=0,05$, dengan demikian nilai $F$ hitung $>\mathrm{f}$ tabel sehingga $\mathrm{H}_{0}$ ditolak,artinya $\mathrm{Hi}$ diterima dengan nilai 0,185 > 0,05. Artinya secara bersama-sama insentif dan Kinerja berpengaruh secara signifikan terhadap Kinerjapegawai Pada Kantor Camat Merapi Barat Kabupaten Lahat 


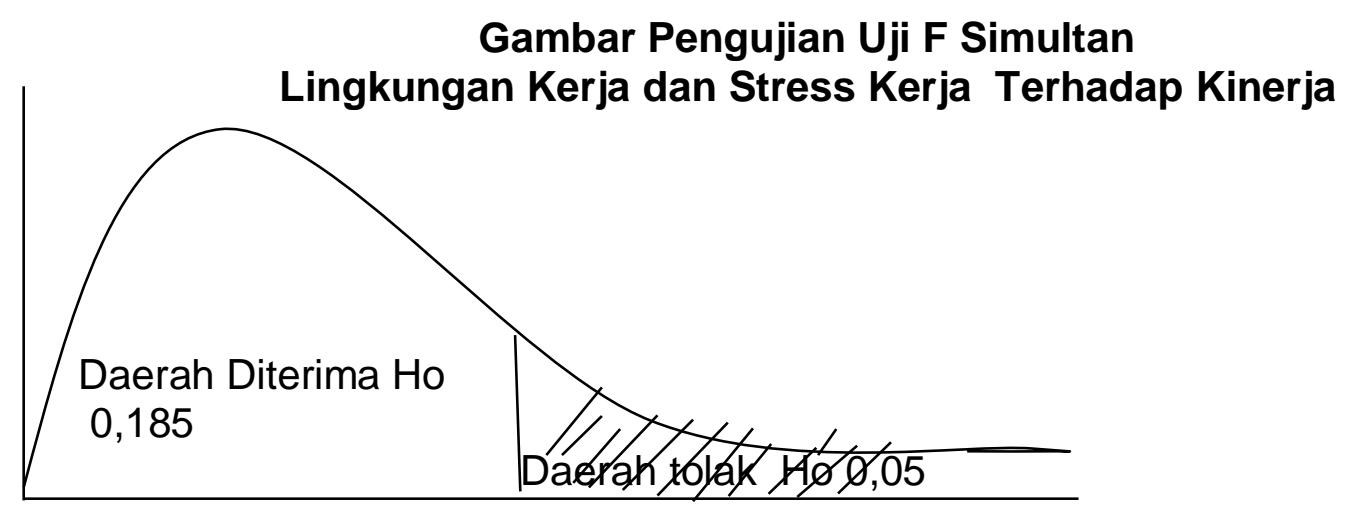

E. KESIMPULAN DAN SARAN

1) Kesimpulan

Sesuai dengan hasil analisis terhadap data penelitian, dapat diambil beberapa kesimpulan sebagai berikut :

1. Variabel Lingkungan Kerja memiliki pengaruh signifikan terhadap Kinerja pegawai Pada Kantor Camat Tebing Tinggi Kabupaten Empat Lawang

2. Variabel Stress Kerja memiliki pengaruh signifikan terhadap Kinerja pegawai Pada Kantor Camat Tebing Tinggi Kabupaten Empat Lawang

3. Variabel Lingkungan Kerja dan Stress Kerja secara bersama-sama mempunyai pengaruh secara signifikan terhadap Kinerja pegawai Pada Kantor Camat Tebing Tinggi Kabupaten Empat Lawang

\section{2) Saran}

Berdasarkan kesimpulan yang diperoleh dalam penelitian ini, maka diajukan saran-saran sebagai berikut

a. Hendaknya pimpinan yang ada pada Kantor Camat Tebing Tinggi agar memperhatikan Kondisi Lingkungan kerja yang ada sekarang, baik itu lingkungan kerja internal maupun eksternal. Karena dengan memperhatikan kondisi lingkungan internal kerja yang ada didalam lingkungan kantor akan dapat meningkatkan semangat pegawai dalam bekerja, seperti mengadakan perbaikan mobilier yang ada, menggantikan semua peralatan bekerja yang sudah tidak layak pakai, menambahkan penerangan yang secukupnya, serta menambahkan kelengkapan bekerja yang dianggap sangat diperlukan

b. Memberikan perhatian serta memotivasi setiap pegawai yang ada, dengan memberikan waktu luang untuk mengadakan diskusi secara terbuka, mengadakan kegiatan arisan keluarga kantor, mengadakan wisata bersama, makan bersama, sehingga pegawai tidak merasa bosan setiap kali akan bekerja.

c. Untuk memberikan pelayanan kesehatan yang rutin kepada seluruh pegawai yang ada, memberikan bantuan sembako, dan baik lagi kegiatan yang bisa dilakukan untuk meningkatkan kinerja pegawai dalam bekerja.

\section{DAFTAR PUSTAKA}

Fahmi, Irham. (2017). Analisis Laporan Keuangan. Alfabeta, Bandung. 
Ghozali, Imam. (2011). Aplikasi Analisis Multivariate Dengan Program SPSS. Semarang: Badan Penerbit Universitas Diponegoro.

Oktariansyah. (2020). Pengaruh Karakteristik Individual dan Lingkungan Kerja Terhadap Kinerja Pegawai Kantor Dinas Transmigrasi Kabupaten Banyuasin. Jurnal Media Wahana Ekonomika, Vol. 17 No.2, Juli 2020 (164-178)

Sugiyono. (2016). Metode Penelitian Manajemen. Bandung: ALFABETA

Sugiyono. (2017). Metode Penelitian Kuantitatif, Kualitatif, dan R\&D. Bandung: Alfabeta.

Sujarweni, Wiratna. 2014. Metodelogi Penelitian. Yogyakarta: Pustaka Baru Pres

Sujarweni, Wiratna. (2016). Analisis Laporan Keuangan. Yogyakarta : Pustaka Baru Press.

Sedarmayanti, (2017). Sumber Daya Manusia Produktivitas Kerja, Madar Maju, Bandung

Usman, B, dkk. (2020). Pengaruh Gaya Kepemimpinan, Lingkungan Kerja dan Stres Kerja Terhadap Kinerja Pegawai Pada Dinas Ketahanan Pangan Dan Peternakan Kota Palembang. Jurnal Media Wahana Ekonomika, Vol. 18 No.1, April 2021 (18-33)

Umar, Husein. 2010. Metode Penelitian Aplikasi dalam Pemasaran. PT. Gramedia Pustaka Umum : Jakarta. 